\section{Ks. Zdzisław Żywica}

Uniwersytet Warmińsko-Mazurski w Olsztynie zjzywica@poczta.onet.pl

DOI: http://dx.doi.org/10.12775/BPTh.2016.038

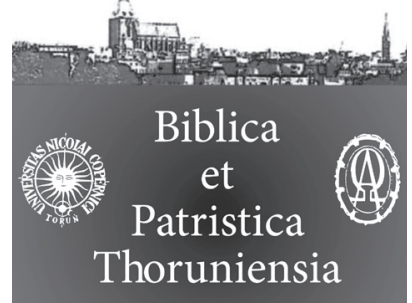

9 (2016) 4: 131-148

ISSN (print) 1689-5150

ISSN (online) 2450-7059

\title{
Kryteria wiarygodności Jezusa i Kościoła w świetle J 6,60-7,53
}

\section{The criteria for the credibility of Jesus and the Church in the light of the $J 6,60-7,53$}

Streszczenie. Autor studium egzegetycznego, kierując się w prowadzonych badaniach faktem dwupoziomowości narracji ewangelicznej, koncentruje się na przesłaniu Ewangelisty Jana, jakie kieruje on do reprezentowanego przez siebie Kościoła w kwestii ponownej misji ewangelizacyjnej wśród współczesnych mu wyznawców judaizmu (Żydów). Z analizy sekcji 6,60-7,53 wynika, że widzi on nie tylko jej konieczność, ale podaje też kryteria jej wiarygodności i skuteczności. Zalicza do nich przede wszystkim prawość i szukanie chwały Bożej. Wskazane Kościołowi kryteria to atrybuty Jezusa z czasów Jego historycznej działalności w Jerozolimie w czasie święta Sukkot.

Abstract. The author of exegetical study, guided in this study by two-level Gospel narration, focuses on the message of John the Evangelist, which is directed to the church they represent in terms of the re-evangelizing mission among contemporary Jews. The analysis of section 6,60-7,53 indicates that he sees not only its necessity but also gives criteria for the credibility and effectiveness. These include mainly integrity and look for the glory of God. The criteria indicated to the Church concern the attributes of Jesus from the time of his historical activity in Jerusalem during Sukkot celebration.

Słowa kluczowe: Żydzi; Jezus; bracia; misja; spory; prawość; sprawiedliwość Boża; chwała Boża.

Keywords: Jews; Jesus; brothers; mission; disputes; righteousness; justice of God; glory of God.

We współczesnej literaturze biblijnej panuje dziś dość powszechne przekonanie, że redaktorzy kanonicznych Ewangelii opowiadają o Jezusie na dwóch podstawowych poziomach: na chronologicznie pierwszym poziomie historycznego Jezusa i Jego uczniów oraz na wypływającym z niego poziomie 
ich współczesności i wspólnot Kościołów, jakie reprezentują. Niektórzy egzegeci mówią o dwóch horyzontach lub poziomach świadectwa, czy też o podwójnej osi: historycznej i teologicznej. Także według teorii lingwistycznej należy mówić o dwóch poziomach komunikacyjnych: intertekstualnym i ekstratekstualnym. Oznacza to, że w przekazie Ewangelisty Jana sytuacja ziemskiego Jezusa i Jego pierwszych uczniów rzutuje na życie i działalność uczniów po Jego zmartwychwstaniu. Należy mieć zatem świadomość, że w uczniach historycznego Jezusa należy widzieć również współczesną Janowi wspólnotę Kościoła, w której on żyje i redaguje Ewangelię o Jezusie i Jego zbawczym dziele. Stąd też, podobnie jak u Synoptyków, kluczowe słownictwo, jak chociażby uczniowie, bracia, naśladować, nie opisuje jedynie życia historycznego Jezusa i uczniów, lecz również egzystencję osobistą Ewangelisty i reprezentowanego przez niego Kościoła w konkretnych uwarunkowaniach czasu i miejsca. Zatem odczytując ponownie Ewangelię według św. Jana, wnikliwie rozróżniając pomiędzy tymi dwoma poziomami, można zapytać: czy jesteśmy w stanie dociec głębszej prawdy o tym, jak Ewangelista rozumiał współczesność i przyszłość Kościoła, który dziedziczył tradycje biblijnej przeszłości Izraela i historycznej osoby Jezusa Mesjasza i Syna Bożego? Do jakich końcowych wniosków doszedł i jakie chciał otworzyć przed Kościołem perspektywy na przyszłość w jego relacji do narodu Jezusa, szczególnie w sytuacji, w której głoszenie Jego Ewangelii nie tylko w Judei, lecz także w diasporze znalazło się w głębokim kryzysie, na co bez wątpienia miała wpływ niezmiennie wroga postawa religijnych przywódców, wojna żydowska i zburzenie świątyni oraz odradzający się po-świątynny judaizm pod przewodnictwem faryzeuszów z Jabne. Czy Ewangelista w ogóle jeszcze myślał o możliwości prowadzenia misji ewangelizacyjnej wśród Żydów? Jeśli tak, to w jaki sposób chciał ją na nowo podjąć w narodzie, do którego Bóg posłał swojego Syna i Mesjasza, a ten w swej większości Go odrzucił? Czy też był już przekonany, że należy ostatecznie pogodzić się z zaistniałą sytuacją i zająć się przede wszystkim losem Kościoła i jego misji wśród pogan. Jeśli tak rzeczywiście myślał, to jak wyobrażał sobie, jeżeli nad tym w ogóle się zastanawiał, realizacje planu zbawienia wobec narodu, od którego całe to dzieło Bóg rozpoczął w powołaniu Abrahama i dopełnił w osobie i dziele Jezusa? Czy nie był świadom tego, że Jezus wybrał Dwunastu i zbudował na nich Kościół w tym celu, żeby ten kontynuował dzieło zbawcze również wśród tych, którzy Go odrzucili? Czy wie na kim i na czym powinien oprzeć argumentację swojego przesłania do braci Kościoła, by ci ze zrozumieniem je przyjęli i wprowadzili w czyn? I w końcu, czy wskazuje kryteria, które powinni oni uznać za fundamentalne w prowadzeniu skutecznej ewangelizacji. 


\section{Niewiara uczniów i braci Jezusa - przygotowanie misji $(6,60-7,13)^{1}$}

Po wygłoszeniu mowy o chlebie życia w synagodze w Kafarnaum (6,1-59) wielu uczniów (mathētai) na stałe opuściło Jezusa $(6,66)$. Zgorszyło ich bowiem zaproszenie do spożywania ciała i picia Jego krwi (6,60n). Okazało się, że na tym etapie nie byli jeszcze w stanie właściwie zrozumieć i zaakceptować usłyszanych słów. Gdyby, pomimo niezrozumienia, pozostali jednak przy wybranym przez siebie Nauczycielu, to stworzyliby tym sobie i Jemu szansę na dalszą edukację pozwalającą na głębsze zrozumienie trudnej nauki Mistrza (6,60-66). Ostatecznie pozostało przy Nim jedynie grono Dwunastu, którzy też nie do końca przecież rozumieli Jego nauczanie. Dlatego też wiedząc o tym, pyta ich, czy i oni chcą Go opuścić. W odpowiedzi Szymon Piotr, w imieniu pozostałych Apostołów, oświadcza, że nie odejdą od Niego jak inni, ponieważ w przeciwieństwie do nich są przekonani, iż tylko On w Izraelu głosi „słowa życia wiecznego", gdyż jest Świętym Boga (hagios tou theou) ${ }^{2}$. Choć zabrzmiało to optymistycznie i dobrze rokująco na przyszłość, to zaraz jednak Jezus dodaje, że jeden z nich, a konkretnie Judasz - syn Szymona Iskarioty, w odróżnieniu od odchodzących uczniów, wyda Go, ponieważ jest diabłem $(6,64.67-71)^{3}$. Stwierdzeniem, że Judasz jest diabłem i dlatego wyda Jezusa, Ewangelista nie tylko kreśli zasadniczą różnicę między jednym z Dwunastu a opuszczającymi Go

1 Ze względu na tematykę studium materiał narracyjny J 6,60-7,53 zostanie podzielony według kryterium osób i ich postaw wobec Jezusa: 6,60-7,13: niewiara uczniów i braci Jezusa - przygotowanie misji; 7,14-19: dysputa Jezusa z Żydami; 7,20-24: dysputa Jezusa z tłumami; 7,25-31: dysputa Jezusa z niektórymi mieszkańcami Jerozolimy; 7,32-53: reakcja żydowskich elit, tłumów i straży na działania Jezusa.

2 Jego godność mesjańską uznali już w 1,41.45 i najwyraźniej nadal ufają zapewnieniom o pochodzeniu od Boga (6,37.44.65). Ewangelista ukazuje posłannictwo Jezusa w świetle świętości Boga $(10,36 ; 17,11.19)$, co stanowi argument za Jego Boską godnością jako Jednorodzonego Syna. Określenie Święty Boga spotykamy również u Synoptyków (Mk 1,24; Łk 4,34). Por. L. Stachowiak, Ewangelia według św. Jana, s. 233.

3 Ewangelista antycypuje tu informacje z 13,2.27. Należy zaznaczyć, że nazwanie Judasza diabłem, jest ściśle powiązane z czynem wydania Jezusa, a nie z Jego opuszczeniem. Ewangelista różnicuje w ten sposób jakość moralną tych dwóch działań. Drugie jest wyraźnie związane z działaniem diabła - przeciwnika Boga. Zatem samo opuszczenie Jezusa nie jest jednoznacznie definiowane jako współdziałanie z diabłem przeciwko Bogu i Jego Synowi. To ważna informacja dla Kościoła reprezentowanego przez Ewangelistę w kwestii nie tylko oceny przypadków apostazji jego członków, ale też i sensu działań misyjnych wśród tych wyznawców judaizmu faryzejsko-rabinicznego, którzy wcześniej w Judei opuścili Jezusa. 
uczniami, lecz sygnalizuje również istotę sporu Jezusa z religijnymi elitami żydowskimi jaki będzie prowadził w czasie Święta Namiotów $(7,1-10,21)^{4}$. Okażą się podobni do Judasza, gdy powie o nich, że ich ojcem jest diabeł $(8,44)$, czym określa charakter ich działania: wydadza Go.

Po tych wydarzeniach, wyglądających na bardzo rujnujące dotychczasowy wysiłek Jezusa w budowaniu własnego Kościoła w Izraelu, kontynuuje On swoją działalność w Galilei (7,1a). Nie chce iść do Jerozolimy na żydowskie Święto Namiotów $(7,2)^{5}$, ponieważ ma świadomość złowrogich zamiarów obecnych tam religijnych elit, o czym informuje wprost Ewangelista $(7,1 b)^{6}$. Jego bracia namawiają Go jednak, aby udał się do Judei. Motywują to tym, że Jego uczniowie powinni zobaczyć dzieła jakich dokonuje $(7,3)^{7}$, oraz żeby objawił się przez nie światu $(7,4)^{8}$. Zapewne myślą, że Święto Namiotów to dobra okazja, by dotrzeć do tych uczniów, którzy Go opuścili oraz by pokazać się również Żydom przybyłym z diaspory z całą mocą dzieł Bożych dokonywanych dotąd, a przez nich również światu pogańskiemu, w którym żyją oni na co dzień9 ${ }^{\text {. Ale }}$

4 Święto Namiotów (Sukkot) obchodzono przez osiem dni dla upamiętnienia pobytu Izraela na pustyni i zamieszkiwania tam w namiotach (Wj 23,16), co symbolizowało całkowitą zależność od Boga $(\mathrm{Oz}$ 2,15). Przypadało w czasie winobrania. Było świętem radości i szczęścia. Jego przebieg opisuje Kpł 23,33-36.39-43; Pwt 16,13-15; TB Sukka 5,2-4. W czasach Jezusa należało do najważniejszych i najpopularniejszych świąt pielgrzymkowych (obok Paschy i Pięćdziesiątnicy). W czasie obchodów mężczyźni mieli obowiązek udania się do świątyni w celu złożenia dziękczynnych ofiar za Boże błogosławieństwo, stąd też gromadziło w Jerozolimie liczną rzeszę pielgrzymów z kraju i diaspory.

5 Zwrot $\dot{z} y$ dowskie w odniesieniu do Święta Namiotów świadczy, że Ewangelista patrzy na te wydarzenie również z perspektywy własnej i reprezentowanego przez siebie Kościoła. Por. R. Schnackenburg, Das Johannesevangelium, s. 192.

6 O zamiarze zabicia Jezusa wiadomo już od 5,18.

7 Czy miałyby pełny sens słowa Ewangelisty, gdyby mówił tu tylko o historycznych uczniach Jezusa? Przecież byli już świadkami Jego wielkich dzieł $(2,1-12 ; 5,1-18 ; 6,1-15$; $6,16-21)$.

8 Ewangelista ma tu zapewne na myśli również tych wszystkich uczniów, którzy opuścili Go po wygłoszeniu mowy o chlebie żywym $(6,66)$. Jednak terminy uczniowie (mathētai) i bracia (adelfoi) mają tu również sens eklezjalny i oznaczają członków Kościoła Jezusa zmartwychwstałego - Kościóła reprezentowanego przez Ewangelistę. Por. L. Stachowiak, Ewangelia według św. Jana, s. 224. Koniec pierwszego wieku to lata prześladowań chrześcijan w Imperium Rzymskim. Dlatego to również czas utraty wiary w Jezusa skutkującej niejednokrotnie apostazją oraz brak nowych wyznawców ze względu na obawy o własne życie. Por. R. Schnackenburg, Das Johannesevangelium, s. 193-196; J. Łach, Bracia Jezusa, s. 257-264.

9 Być może bracia (bliscy krewni) pragną manifestacji mesjańskiej mocy Jezusa po to, żeby stworzyć pretekst do okrzyknięcia Go mesjaszem politycznym, lub też tak po ludz$\mathrm{ku}$, dowartościować samych siebie osobą krewnego w tak licznym gronie rodaków z kraju 
czy rzeczywiście chodzi tu Ewangeliście tylko o utraconych uczniów i świat diaspory współczesnych Jezusowi Żydów? A może również o byłych uczniów i Żydów jego czasów, tych, którzy odrzuciwszy Jezusa, przestali reprezentować tym samym naród wybrany (dzieci Abrahama), stając się częścią świata pogańskiego? Skoro tak, to czy Ewangelista nie ma tu na myśli również czasów, w których sam żyje? Czy nie chce zaprosić braci Kościoła, który reprezentuje ${ }^{10}$, do podjęcia nowej działalności misyjnej wśród Żydów ${ }^{11}$ zamieszkujących Judeę i świat Pogan ${ }^{12}$, pomimo wrogości, jaka między nimi zapanowała? Początkowo również Jezus nie chciał podejmować się tego dzieła, mimo nalegań Jego braci. Czy Ewangelista wraz z braćmi Kościoła reprezentującymi podobne przekonania, nie zdradza tu zamiaru posłania ewangelizatorów do Judei, by ci poszli z Jezusem zmartwychwstałym ponownie i dokonali tam razem z Nim dzieł jakich dokonywał On sam w czasach ziemskiej działalności? Czy nie jawne (ou fanerōs) lecz $w$ ukryciu (en kryptō) udanie się Jezusa do Jerozolimy, szukanie Go wśród tłumu, skrywane dyskusje z obawy przed Żydami, nie wskazują również na czasy obecności Jezusa zmartwychwstałego w działalności braci Kościoła

i diaspory. O niewierze braci Jezusa informują również Synoptycy (Mk 3,20-21.31-35; Mt 12,46-50). Niektórzy z nich uwierzyli w Jezusa po zmartwychwstaniu i zajmowali czołowe miejsca w Kościele jerozolimskim. Ich wiara jednak nadal cechowała się dużym legalizmem judaistycznym (Dz 12,17; 15,13-21; 2,9). Por. T. Okure, Ewangelia według św. Jana, s. 1336n.

10 W którym też kształtuje się jego Ewangelia oraz dla którego jest ona jednocześnie pisana.

11 Termin $\dot{Z} y d z i$ w 7,1-10,21 na poziomie czasów Jezusa odnosi się do religijnych elit żydowskich, natomiast czasów Ewangelisty to ogół wyznawców judaizmu faryzejskorabinicznego po definitywnym rozejściu się dróg Kościoła i Synagogi okresu jabneńskiego. Więcej na ten temat zob. A. Paciorek, Ewangelia umiłowanego ucznia, s. 107-110; Z. Żywica, Kościół Jezusa, s. 22-30; M.S. Wróbel, Antyjudaizm, s. 79-91. 93-145. 153-155.

12 Idea, że Żydzi którzy odrzucili Jezusa stali się w statusie historio-zbawczym równi Poganom, nie jest obca w czasach apostolskich. Widać ją wyraźnie choćby u Pawła w Liście do Rzymian (2-3). Stąd też Żydzi reprezentujący świat (kosmos) stanowiliby tu wrogą Jezusowi jego część od samego początku działalności. Drugą część natomiast stanowiliby Poganie, którzy nie moga nienawidzić Jego uczniów $(7,7)$, ponieważ działają w świecie pokojowo, głosząc Ewangelię miłości Bożej objawionej w Jego Synu Chrystusie. Taki stan ewangelizacji świata pogańskiego potwierdza szybki rozwój Kościoła Jezusa, o czym informują Dzieje Apostolskie i Listy Pawła. Źródła te wskazują również, że wiele wrogości do chrześcijan budzili w przywódcach pogańskich sami Żydzi. Wrogość i prześladowania czasów Domicjana, do których odnosi się tu zapewne Ewangelista, nie osiąga w jego narracji szczególnie wyjątkowego miejsca i zradykalizowanej formy. Autor chce niewątpliwie zasugerować w ten sposób, że możliwe jest pokojowe współistnienie Kościoła i narodów Cesarstwa, pomimo przypadków wrogości jego elit politycznych. Por. A. Paciorek, Ewangelia umiłowanego ucznia, s. 111-113. 
$(7,10-13)^{13}$ ? Choć Jezus uważał, że Jego czas (kairos) jeszcze się nie dopełnił ${ }^{14}$, to jednak ostatecznie udał się do Jerozolimy, by podjąć wysiłek przekonania do siebie i swojej nauki wrogo nastawione elity żydowskie. Nie ulega presji braci, lecz demonstruje suwerenne wypełnianie jedynie woli swego Ojca, który posłał Go, aby dać życie wszystkim tym, którzy w Niego uwierzą i wyznają Go jako Syna Bożego. Sytuacja braci Kościoła Jezusa zmartwychwstałego jest już inna, dlatego czas (kairos) na ewangelizację jest właściwy, gdyż świat ich nie nienawidzi tak jak to było wcześniej z Jezusem $(7,6 \mathrm{n})$. Może powinni podjęć nową próbę ewangelizacji wrogich Jezusowi braci swego narodu ze względu na wspólne dziedzictwo Abrahama? Czy wyznaniem, że nawet bracia nie wierzyli w Jezusa $(7,5)$, nie ekstrapoluje Ewangelista również do tych braci Kościoła, którzy w jego czasach nie wierzyli, że można jeszcze nakłonić współczesnych im wyznawców judaizmu do wiary w Jezusa zmartwychwstałego, skoro nie przekonał ich On sam w czasie ziemskiej działalności ${ }^{15}$ ?

\section{Dysputa Jezusa z Żydami (7,14-19)}

Na pytanie Żydów, skąd Jezus zna Pisma, skoro się ich nie uczył $(7,15)$, odpowiada, że nauka jaką głosi nie jest Jego, lecz Tego, który Go posłał $(7,16)$. Pytającym nie chodzi o znajomość treści ksiąg biblijnych, lecz o umiejętność ich interpretacji i wykładni, czego można się było nauczyć jedynie u ówczesnych wybitnych nauczycieli i mistrzów. To znaczy w szkołach uczonych w Piśmie, reprezentujących ugrupowania żydowskie, a wśród nich szczególnie faryzejskie i saducejskie ${ }^{16}$. Jezus nie studiował w żadnej z nich, stąd też od razu dostrzegli w Jego nauce radykalną odmienność od ich własnej.

W udzielonej odpowiedzi Jezus zarysowuje nie tylko zasadniczą różnicę między Nim samym a adwersarzami. Jeżeli bowiem oświadcza, że Jego nauka pochodzi od Boga, a ta jest tożsama z nauką Pism, co poświadczają w posta-

13 Zarzuty o zwodzeniu tłumów były stawiane przez religijnych przywódców żydowskich zarówno Jezusowi jak i Jego Kościołowi. Rozumiano pod nim przede wszystkim odstępstwo od tradycji ojców, czyli interpretacji Tory judaizmu świątynnego i po-świątynnego.

14 Użyty tylko w tym miejscu Ewangelii rzeczownik czas ma praktycznie to samo znaczenie, co licznie stosowny termin godzina i opisuje wydarzenia paschalne w Jerozolimie: mękę, śmierć i zmartwychwstanie Jezusa. Por. L. Stachowiak, Ewangelia według św. Jana, s. 225.

15 R. Schnackenburg, Das Johannesevangelium, s. 197-200.

16 Przykładem jest tu Paweł (Dz 22,3). 
wionym pytaniu ${ }^{17}$, to tym samym wykazuje w nich brak logicznego myślenia lub też złą wolę w stosunku do Niego. Jezus, wykorzystując ich logikę myślenia zaprezentowaną w pytaniu, wskazuje, że skoro sami uznają znajomość wykładni Pism przez Jezusa, bez ich wcześniejszego uczenia się w ich środowiskach, to powinni widzieć w Nim kogoś pochodzącego od Boga, i to bardzo Mu bliskiego skoro tak dobrze zna Jego wolę zawartą w Pismach, czym są sami $z d u$ mieni (ethaumadzon) ${ }^{18}$. Jezus deklaruje, że nie pełni swojej woli gdy naucza i działa, lecz wolę Tego, który Go posłał. Gdyby zatem i oni pełnili wolę Boga zapisaną w Pismach, to uznaliby w Jezusie Posłańca Bożego, który reprezentuje Go w pełnej zgodności z tym, co mówi On do swego ludu w Pismach. Jezus jest nadzwyczaj konsekwentny w swym działaniu. Skoro bowiem nie mówi we własnym imieniu, to też i nie szuka własnej chwały, lecz chwały Tego, którego wolę pełni ${ }^{19}$. To zaś jest ewidentnym dowodem na Jego prawdziwość (alēthēs) ${ }^{20}$ i na brak w Nim niesprawiedliwości (adikia), co oznacza, że jest prawdomówny i prawy, a przez to godny całkowitego zaufania w tym co mówi o sobie i własnym posłannictwie $(7,17 \mathrm{n})$. W ten oto sposób Jezus określa fundamentalną różnicę między sobą a religijnymi elitami. Oni bowiem, choć - jak są głęboko przekonani - dobrze znają i wykładają Prawo Mojżeszowe jednoznacznie zabraniające przecież zabijania, to jednak już od dawna z premedytacją dążą do zabicia Jezusa $(7,19)^{21}$. W oczywisty zatem sposób udowadniają tym, że nie wykonują woli Bożej, do przestrzegania której zobowiązali się w Przymierzu z Nim zawartym. Manifestują ostentacyjnie, że nie tylko mówią we własnym imieniu, ale też i działają według własnej woli, szukając osobistej chwały, korzyści, władzy i jej splendoru, a nie chwały Bożej - co jest ich konstytutywnym

17 Zastanawiają się nad źródłem Jego nauki, która jest tożsama z nauką Pism. Tę zaś uznają za spisaną wolę Bożą objawianą w dziejach narodu. Por. S. Włodarczyk, „Skąd zna on Pisma, skoro się nie uczyt?" (J 7,15), s. 223-231.

18 Ich $z$ dumienie dotyczy interpretacji i wykładni Pism, a nie ich literalnych treści.

19 Temat szukania prawdy Jezus poruszył już w 5,44, gdzie również jednoznacznie stwierdził, że własna chwała nie stanowi celu ani motywu Jego działania.

20 Prawdziwość należy rozumieć jako prawość, czyli harmonijną zgodność między własnym życiem a wyznawaną prawdą.

21 O Mojżeszu jako oskarżycielu Żydów Jezus mówił już w 5,45. Natomiast jako o świadku poświadczającym prawdziwość posłannictwa Jezusa i Jego nauki w 5,46n. 
obowiązkiem $^{22}$. To zaś jest niezbitym dowodem na ich nie-prawdziwośćc ${ }^{23}$ - nieprawość, która w konsekwencji czyni ich niesprawiedliwymi przed Bogiem²4.

\section{Dysputa Jezusa z tłumami $(7,20-24)$}

Wydaje się, że tłumy (ochloi) nie są nastawione do Jezusa aż tak agresywnie złowrogo jak ich elity religijne, co może wynikać z wypowiedzi skierowanej do Niego, gdy zarzucił ich przywódcom, że chcą Go zabić. Zdecydowanie jednak stają w ich obronie. Słowa Jezusa o zamiarze zabicia Go uważają za coś tak absurdalnego, że mogą być one jedynie wypowiedziane pod wpływem demona. Skoro zaś Jezus tak uważa, to w ich przekonaniu, potwierdza tylko że rzeczywiście jest opętany $(7,20)^{25}$. W odpowiedzi na tę insynuację, Jezus wykazuje brak prawości również w ich postawie. Otóż żywią do Jezusa złość, wściekają się na $\mathrm{Niego}^{26}$, dlatego że postępuje podobnie jak oni sami z ich elitami. Złoszczq się na Jezusa $z$ powodu uzdrowienia chromego w szabat (5,1-18), a tymczasem dokonują obrzezań również w szabat ${ }^{27}$. Nie postrzegają jednak swego działania jako łamanie Prawa. Natomiast gdy Jezusa uzdrawia chorego, to uważają to za naruszenie spoczynku szabatu. Dlatego, reagują zdecydowanym oskarżeniem

22 Mieli też tego nauczać lud powierzony ich duchowej opiece.

23 Ich przymiot nie-prawdziwości jest zaprzeczeniem atrybutu Jezusa prawdziwości $(7,18)$. W myśli żydowskiej, którą przecież reprezentują, poznanie Boga znaczy bliski z Nim związek, a nie abstrakcyjne idee z Nim związane. Por. T. Okure, Ewangelia według św. Jana, s. 1337.

24 Podobnie rzecz wygląda i w kwestii drugiego atrybutu Jezusa. Jest w Nim brak niesprawiedliwości $(7,18)$, podczas gdy oni wydają niesprawiedliwe wyroki $(7,24)$. Por. A. Paciorek, Ewangelia umiłowanego ucznia, s. 321; L. Stachowiak, Ewangelia według św. Jana, s. 227.

25 Opętanie przez demona było dość powszechnie utożsamiane z utratą zmysłów (J 8,48.52; 10,20). Z zarzutem działania Jezusa mocą Belzebuba spotykamy się w Mk 3,22. Jeżeli tłumy rzeczywiście nic nie wiedzą o zamiarze zabicia Jezusa przez religijnych przywódców, oznacza to, że są przez nich oszukiwani. To zaś jest kolejnym świadectwem ich głębokiego zdeprawowania.

26 Zastosowany tu czasownik cholaō oznacza: być złym, być rozgniewanym, złościć się, wściekać się na kogoś; dosłownie: wylewać żółć. Forma rzeczownikowa cholē oznacza: żótć, gorycz.

27 Obrzęd obrzezania sięga czasów patriarchalnych (Rdz 17,9-14; 34,15nn). Prawo Mojżeszowe nakazywało dokonać obrzezania chłopca ósmego dnia po jego narodzeniu (Kpł 12,3). Jeżeli zaś ósmy dzień przypadał w dzień szabatu, to - zgodnie z interpretacją uczonych w Piśmie - ceremonię obrzezania należało przeprowadzić w tym właśnie dniu (TB Szab 132a). Por. L. Stachowiak, Ewangelia według św. Jana, s. 228. 
Go o łamanie Prawa Bożego, co wyklucza, w ich mniemaniu, możliwość Jego pochodzenia od Boga. Jezus wskazuje na sprzeczność w ich myśleniu i postępowaniu wówczas gdy ta sama sprawa dotyczy ich oraz Jego osoby. Sprzeczność ta jest identyczna z tą, w jakiej znajdują się ich religijni zwierzchnicy. Dlatego napomina ich i jednocześnie wzywa do głębszego spojrzenia na wewnętrzny konflikt, w który są uwikłani. Zachęca, by nie kierowali się powierzchownością i stronniczością, lecz kierując się sprawiedliwością Bożą, spojrzeli głęboko w swoje serca i dostrzegli w nich niesprawiedliwość i nieobrzezanie $(7,20-24)$. Choć stopień wrogości wobec Jezusa religijnych elit i stających w ich obronie tłumów nie jest przedstawiony tu jako tożsamy ${ }^{28}$, to nie ulega wątpliwości, że tak samo uwikłani są w wewnętrzną sprzeczność między ich postępowaniem a wyznawaną prawdą. Słowa Jezusa skierowane bezpośrednio do tłumów dotyczą również i ich przywódców. Tworzą tu bowiem jedną grupę adwersarzy i słuchaczy Jego słów. Wcześniej nie było okazji do wygłoszenia podobnych napomnień tylko do przywódców, ponieważ na oskarżenie ich o zamiar zabicia Go, reagują natychmiast zgromadzone przy nich tłumy $(7,19 n)$. Przedstawienie ich przez Ewangelistę w jednej grupie religijnej i mentalnej, do której kierowane są identyczne słowa, zdradza Jego zamiar ukazania ich jako jednej wspólnoty o tych samych przekonaniach i działaniach, choć w detalach różniących się co do ich formy i intensywności.

\section{Dysputa Jezusa z niektórymi mieszkańcami Jerozolimy $(7,25-31)$}

Niektórzy mieszkańcy Jerozolimy, w przeciwieństwie do tłumów, wiedzą o istnieniu osób usiłujących rzeczywiście zabić Jezusa, choć w pierwszym pytaniu nie podają kogo mają na myśli $(7,25)^{29}$.W drugim natomiast wskazują na zwierzchników (archontes), mając zapewne na myśli religijne elity. Ich dotychczasowy brak działań podczas Święta Namiotów w stosunku do osoby Jezusa każe im domniemywać, że być może dali się przekonać Jego argumentom i uznali w Nim Mesjasza. Zarzucają im bowiem, że Jezus „jawnie przemawia i nic Mu nie mówią" $(7,26)$. Ze słów tych można by wywnioskować, że są przychylnie nastawieni do Jezusa i okazują wręcz zadowolenie z takiego przebiegu sprawy. Jednak ich dalsza wypowiedź pokazuje wręcz coś przeciwnego. Okazu-

28 Tłumy nie dążą do zabicia Jezusa. Dopiero w 7,44 okaże się, że część z nich będzie chciała Go pojmać.

29 Ewangelista wprowadza tu trzecią grupę osób: niektórych mieszkańców Jerozolimy. Prezentuje ją jako odrębną od dwóch wcześniej wymienionych: Żydów i tłumów. 
je się, że jest ona jeszcze bardziej wrogo nastawiona do Jezusa niż poprzednie dwie grupy (Żydzi i tłumy). Zarzucają bowiem zwierzchnikom, że gdyby uwierzyli w mesjańską godność Jezusa postąpiliby sprzecznie z tym, co jest wiadomo o okolicznościach przyjścia Mesjasza, a mianowicie gdy przyjdzie, nikt nie będzie wiedział skąd pochodzi ${ }^{30}$. Wszyscy natomiast wiedzą, skąd jest Jezus, to zaś - w ich przekonaniu - w sposób oczywisty wyklucza Go z oczekiwań mesjańskich $(7,27)$. Skoro wiedzą o tym oni, to tym bardziej powinni to wiedzieć zwierzchnicy. A jeśli wiedzą o tym, to dlaczego do tej pory nie przedsięwzięli żadnych działań przeciwko Jezusowi, przecież od dawna zamierzają Go zabić; a minęła już połowa Świąt $(7,14)$. Zastosowany tu przysłówek prawdziwie (alethōs) w pytaniu niektórych mieszkańców Jerozolimy, charakteryzujący postawę zwierzchników, przywołuj na pamięć rzeczownik prawdziwy (alēthēs) odnoszący się do osoby Jezusa. Dzięki zastosowaniu tej gry słów Ewangelista chce zapewne pokazać, że niektórzy mieszkańcy Jerozolimy, w sposób przez nich nie zamierzony i nie uświadomiony, wypowiadają pełną prawdę o Jezusie, a mianowicie, że jest prawdziwy, tzn. prawy i prawdomówny w tym co mówi o sobie i Bogu. Obawiają się, że zwierzchnicy rzeczywiście poznali prawdę o Jezusie i uznali Go za Mesjasza. Pytają: „czyż nie prawdziwie poznali zwierzchnicy, że ten jest Chrystusem? (mēpote alethōs egnōsan hoi archontes, choti houtos estin ho Christos;" 7,26$)^{31}$. Dla czytelnika staje się jasne, że prawda o Jezusie jest oczywista i wychodzi na światło dzienne nawet w wypowiedziach jej przeciwników, którzy robią wszystko, co możliwe, by ją zanegować. Żeby to świadomie dostrzec, potrzebne jest jednak prawe serce, tj. serce poddane i otwarte na Boga i Jego wolę. Tego jednak brakuje przeciwnikom Jezusa, ponieważ pozwolili zaślepić swe serca nienawiścią do Niego przez ich ojca diabła $(8,44)$, ojca kłamstwa i nieprzyjaciela Boga. Taki stan sprawia, że nawet słowo Boże, znane im przecież z Pism, nie jest $\mathrm{w}$ stanie tego odmienić ${ }^{32}$.

W odpowiedzi skierowanej do tej grupy adwersarzy Jezus potwierdza, że tak naprawdę, to dobrze wiedzą, skąd przychodzi i kim jest, bo przecież wypowiedzieli to w postawionych pytaniach $(7,28)$. Słyszeli, że nie przyszedł z własnej woli, lecz z woli Tego, który jest prawdziwy (alēthinos). Wierzą przecież, że Jedynym Prawdziwym jest sam Bóg Jahwe. A skoro Jezus jest prawdziwy, to znaczy, że pochodzi od Niego. Odrzucając Jezusa, dowodzą, że nie znają swego

30 Zgodnie z rozpowszechnionym wówczas przekonaniem, opartym na 1 Hen 48,6, Mesjasz powinien pozostać zupełnie nieznany przed swym publicznym wystąpieniem. Por. A. Paciorek, Ewangelia umiłowanego ucznia, s. 322; R. Schnackenburg, Das Johannesevangelium, s. 202; J. Łach, Znamienny zapis, s. 24-246.

31 To dlatego chcą im przypomnieć okoliczności przyjścia Mesjasza.

32 Por. M.S. Wróbel, Antyjudaizm, s. 219-222. 
Boga, bo przecież gdyby Go znali w prawdzie objawienia, to uznaliby Jezusa za Jego Pomazańca. Tego jednak nie czynią, czym potwierdzają, że nie znają swego Boga zgodnie z Jego objawiona wola, lecz ciągle kierują się własną jej interpretacją $(7,28)^{33}$. Jezus, w przeciwieństwie do nich, zna Go, ponieważ od Niego jest (eimi) i to On Go wystat (apesteilen) do nich $(7,29)^{34}$. Reakcja na te słowa potwierdza tylko prawdziwość zarzutów Jezusa oraz ich właściwe zrozumienie przez adwersarzy. Pragną Go bowiem pojmać. Jednak nikt nie chce im pomóc w tym zamiarze, ponieważ godzina Jezusa jeszcze nie nadeszła $(7,30)$. Znaczy to, że wszystko dokonuje się zgodnie z wolą Boga i Jego Syna, a nie w godzinie ich spisków i działań. Suwerenem jest tu Jahwe i Jego Syn, a nie religijne elity żydowskie wraz $\mathrm{z}$ ich wszystkimi zwolennikami ${ }^{35}$. Brzmi to w tonie mocno oskarżycielskim, ponieważ Jezus zarzuca im, że nie reprezentują już Boga, stąd też nie mają już prawa uważać siebie dalej za posłanych przez Niego pasterzy do ludu Izraela. Gdyby nadal byli prawdziwie posłani przez Niego, tak jak jest Jezus, to nie postąpiliby wobec Niego tak jak to właśnie próbują uczynić. Jeżeli byliby rzeczywiście prawdziwi - prawi, to poznaliby Jezusa w pełnej prawdzie objawiającej się w Nim woli Bożej. Ich bezsilność i bezskuteczność w pojmaniu Jezusa, tylko tego dowodzi. Niestety, nawet tego nie są w stanie dostrzec i właściwie zinterpretować, a przecież uchodzą za znakomitych znawców i interpretatorów Pism ${ }^{36}$.

Polemika Jezusa z tą grupą mieszkańców Jerozolimy osiągnęła skutek odwrotny do zamierzonego przez adwersarzy. Ci bowiem, argumentami o pochodzeniu Mesjasza, chcieli niewątpliwie utwierdzić zebrane tam tłumy we wrogiej postawie wobec Jezusa. Stało się jednak inaczej. Wiele osób spośród tłumu uwierzyło (episteusan) w Jezusa, uznała Go za Mesjasza (7,31). Nie przemówiły do nich argumenty adwersarzy, lecz znaki dokonywane przez Jezusa. Mówili bowiem: Mesjasz gdy przyjdzie, czy liczniejsze znaki uczyni, od tych które ten uczynit? Tak sformułowane pytanie wyraża ich przekonanie, że nawet zapowiadany Mesjasza, o którym wiele już słyszeli od swych religijnych zwierzchni-

33 W języku biblijnym czasownik poznać oznacza utworzyć jedność z inną rzeczywistością lub osobą. W Ewangelii oznacza zapoznanie $(4,1.53)$, posiadanie znajomości $(7,49)$, zrozumienie $(3,10 ; 10,6 ; 12,16 ; 13,7)$, wiedze $(3,11 ; 7,26 ; 8,55 ; 10,4 ; 13,7 ; 14,7)$. Poznanie zatem to praca umysłu, który usiłuje uczynić niejako własną osobę (rzecz) poznawaną dzięki pełnemu, doskonałemu jej rozpoznaniu. To wzajemne oddanie się, upodobanie pełne serdeczności i miłości; to objawienie się poznanego bytu $(10,14)$. Por. E. Szymanek, Wiara i niewiara, s. 269n.

34 To On „jest na łonie Ojca” $(1,18)$ i to On objawia Go tym, którzy wierzą w Niego $(14,9)$.

35 Por. L. Stachowiak, Ewangelia wedtug św. Jana, s. 229.

36 Por. R. Schnackenburg, Das Johannesevangelium, s. 204n. 
ków, nie uczyniłby więcej i bardziej spektakularnych znaków niż Jezus z Galilei. W zupełnie nieoczekiwany sposób zatem okazuje się, że część tłumu bardziej ufa Jezusowi niż swoim zwierzchnikom. Wyrażona w ich pytaniu wątpliwość co do skuteczności oczekiwanego Mesjasza, w porównaniu do działań Jezusa, może również odsłaniać ich postrzeganie Go jako kogoś większego niż tylko Mesjasz, skoro widzą, że dokonuje On większych dzieł od niego. Jest to zapewne zamierzona przez Ewangelistę sugestia o ich otwartych sercach i umysłach na Boską godność Jezusa ${ }^{37}$.

\section{Reakcja żydowskich elit, tłumów i straży na działania Jezusa $(7,32-53)$}

Reakcja na postawę tłumów wobec Jezusa była natychmiastowa. Faryzeusze gdy tylko dowiedzieli się, że część tłumu uwierzyła w Jezusa, a reszta szeptała (goggydzontos) ${ }^{38}$ o Nim oraz o tym wszystkim, co się dotychczas wydarzyło, poinformowali arcykapłanów. Następnie wspólnie wysłali straż świątynną z nakazem pojmania Jezusa $(7,32)$. Zapewne postąpili tak, aby uniemożliwić dalsze nawrócenia osób z tłumu, wywołując w nich strach o ich własny los.

W odpowiedzi Jezus, w dalszym ciągu pokazywany przez Ewangelistę jako suweren realizujący wolę Boga co do własnego losu, zapowiada nieodległy już powrót do Tego, który Go wysłał do nich $(7,33)$. Zapewnia ich, że pomimo podejmowanych prób odnalezienia Go, nie będą w stanie tego uczynić, ponieważ udaje się tam, gdzie oni pójść nie mogą $(7,34)$. Jezus rekapituluje w ten sposób wcześniejsze swoje wypowiedzi o nich. Nie będą w stanie odnaleźć Go w niebiosach u Boga, ponieważ tu na ziemi nie chcą Go poznać i uznać za Mesjasza i Syna Bożego. Wiedzą przecież doskonale, że w niebiosach znajdą się jedynie ci, którzy za życia ziemskiego pełnią wolę Bożą. Ten zaś warunek, na obecnym etapie, całkowicie ich wyklucza. W odpowiedzi $\dot{Z} y d z i$ zastanawiają się, dokąd może On pójść, skoro nawet oni - religijne elity - nie będą mogli Go znaleźć; do tej pory nie mieli z tym przecież żadnych problemów. Ich zaduma nad słowami Jezusa pokazuje, że ciągle nic nie rozumieją z dokonującej się woli Bożej na tym etapie dziejów Izraela, choć formalnie są jego duchowymi elitami. Za-

37 Dla Kościoła Jana stanowi to wyraźny sygnał, że ewangelizacja wśród wyznawców judaizmu po-świątynnego jest nadal otwarta i obiecująca w nawrócenia.

38 Zastosowany tu imiesłów szepczacy wskazuje na lęk tłumów przed otwartym mówieniem o Jezusie. Podyktowane to było zapewne obawami przed negatywnymi dla nich konsekwencjami ze strony ich religijnych zwierzchników. Skoro Jezusa zamierzali zabić, to również los Jego zwolenników mógł okazać się podobny. 
kładają, że uda się na tereny Greków, tam, gdzie kończy się ich władza, i wśród zamieszkujących tam Żydów oraz Greków będzie dalej prowadził swe dzieło $z w o d z e n i a ~ l u d z i(7,35)$. Ewangelista ponownie stosuje tu termin $\dot{Z} y d z i(7,15.35)$. Chce zapewne wyjaśnić, że na poziomie czasów Jezusa ma tu na myśli religijne elity (szczególnie arcykapłanów i faryzeuszy), pozostałe im wierne tłumy oraz część mieszkańców Jerozolimy ${ }^{39}$. Na poziomie czasów mu współczesnych myśli o wszystkich wyznawcach judaizmu po-świątynnego. Wzmianka o Żydach w diasporze i Grekach wyraźnie dowodzi, że opowiadanie Ewangelisty rozgrywa się na dwóch poziomach historycznych i teologicznych ${ }^{40}$. Udanie się Jezusa na tereny Pogan, może być w zamiarze Ewangelisty kolejnym ostrzeżeniem Żydów przed konsekwencjami eschatologicznymi odrzucenia Jezusa. Zajęcie identycznej postawy wobec Kościoła Jezusa na obecnym etapie zbawienia, może być ostatnią już szansa daną im przez Boga na zbawienie wieczne ${ }^{41}$.

Kolejne wystąpienie Jezusa, zaznaczone przez Ewangelistę, ma miejsce dopiero w ostatnim dniu Święta Namiotów, najbardziej uroczystym, (7,37a; Kpł $23,36)^{42}$. W tym dniu odbywała się procesja $\mathrm{z}$ wodą zaczerpniętą $\mathrm{z}$ sadzawki Siloe, którą kapłan wylewał na ołtarz ofiarny. Składano w ten sposób Bogu dziękczynienie za otrzymane błogosławieństwa i proszono jednocześnie o obfity deszcz w okresie jesiennym mający zapewniać uradzaj w następnych zbiorach. W późniejszym czasie prorocy nadają wodzie głębszą symbolikę i wiążą ją z oczekiwaniami mesjańskimi, wskazując na ich obfite dobrodziejstwa ${ }^{43}$. W czasach Jezusa taką właśnie symbolikę niósł ze sobą ten obrzęd. Jezus nawiązuje do tej tradycji i zaprasza wszystkich wierzących w Niego, by przychodzili i pili wodę, którą On daje. Stwierdza tym samym, że oczekiwania mesjańskie wypełniają się właśnie w Jego osobie i dokonywanym przez Niego dziele, że w Nim oczekiwane dobrodziejstwa stają się dostępne w całej swej eschatologicznej pełni. Jednak, co wyraźnie wynika z Jego słów, są one dostępne tylko

39 Temu celowi służyło zapewne ich wcześniejsze przywołanie w 7,15.20.25.

40 Wzmiankę o domniemanym udaniu się Jezusa na tereny pogan, na poziomie Jego historycznej działalności, można potraktować również jako wyraz pogardy ówczesnych elit wobec Jezusa.

41 Por. A. Paciorek, Ewangelia umiłowanego ucznia, 322; R. Schnackenburg, Das Johannesevangelium, s. 206-209. Narracja 7,32-36 ma również na celu przygotowanie do słów Jezusa z 7,37-39, reakcji zgromadzonych tam tłumów $(7,40-44)$ oraz strażników, arcykapłanów i faryzeuszy $(7,45-53)$.

42 Był to ósmy dzień Świąt. Obchodzono go bardziej uroczyście niż poprzednie, stąd też stanowił niejako oddzielne święto. Obejmował modlitwę o deszcz, rozważanie o kruchości ludzkiego życia oraz wspomnienie zmarłych. Por.T. Okure, Ewangelia według św. Jana, s. 1336.

43 Por. A. Paciorek, Ewangelia umiłowanego ucznia, s. 322. 
dla tych, którzy w Niego wierzą (ho pisteuōn eis eme). Zatem warunkiem ich dostąpienia jest wiara w Jezusa, a nie tylko obecność przy Nim w czasie Jego działalności (7,37b-38a). Wszystko zaś to dokonuje się zgodnie z Pismem, które o tym wyraźnie mówi od wieków: „Strumienie wody żywej popłyną z jego wnętrza" $(7,38 b)^{44}$. Ewangelista wyjaśnia, że Jezus mówiąc o wodzie żywej ma na myśli Ducha, którego mieli otrzymać wierzacy w Niego $(7,39 a)^{45}$, czym ponownie nawiązuje do tradycji prorockiej, w której wielokrotnie jest mowa o życiodajnym działaniu Ducha ${ }^{46}$.

Tym razem również Ewangelista deklaruje, że otrzymają Go jedynie wierzący w Jezusa. Niewątpliwie deklarację tę kieruje również do adresatów Ewangelii, rozstrzygając jednoznacznie, że zapowiadane dobrodziejstwa mesjańskie wypełniły się definitywnie już w Jezusie, i żadne inne nie nadejdą w żadnym innym Pomazańcu Bożym.

Na wypowiedź Jezusa o żywej wodzie reaguje tłum $(7,41 \mathrm{n})$, podobnie jak to miało miejsce na początku Święta, zanim Jezus ujawnił się $(7,12)$. Zgromadzony tłum Ewangelista dzieli na trzy różniące się między sobą grupy pod względem ich postawy wobec osoby Mesjasza. Jedna z nich uważała Jezusa za proroka ${ }^{47}$. Inna za Mesjasza; zapewne ta, która wcześniej już uwierzyła Niego $(7,31)^{48}$. Trzecia natomiast grupa, reaguje wrogo wobec tych, którzy widzą w Jezusie Mesjasza. Radykalnie neguje Jego godność mesjańską, powołując się na przytaczane już wcześniej argumenty dotyczące pochodzenia Mesjasza $(7,27)$. Miał on przecież jako potomek Dawida pochodzić z Betlejem - twierdzą $(7,42)^{49}$. Podobnie jak w poprzedniej odsłonie część tłumu pozostała wierna swym zwierzchnikom i nie uwierzyła w Jezusa. Nadto miała zamiar Go pojmać, lecz nie odważyła się ostatecznie na takie działanie $(7,44)$. Ewangelista wskazuje w ten sposób na bardzo bliskie podobieństwo w myśleniu i działaniu części ludu żydowskiego i ich religijnych zwierzchników ${ }^{50}$.

44 Temat wody dającej życie pojawił się już w 4,14 i 6,35.

45 Trwa ożywiona dyskusja wśród egzegetów na temat obecności i działania Ducha Świętego w czasie działalności Jezusa, przed Jego zesłaniem w dniu Pięćdziesiątnicy. Jako że kwestia ta nie stanowi centrum naszego zainteresowania w niniejszym studium, pozostawiamy ją jako temat do odrębnych badań egzegetycznych.

46 Por. Iz 58,11; Ez 47,1; Za 14,8. Por. R. Schnackenburg, Das Johannesevangelium, s. $211-218$.

47 Zapewne na wzór zapowiedzianego w Pwt 18,15.18.

48 Być może widzą w nim nacjonalistycznego króla żydowskiego z rodu Dawida.

49 Por. 2 Sm 7,12-16; Ps 89 (88), 4-5; 132 (131), 11; Mi 5,1-2; Jr 23,5-6. Por. L. Stachowiak, Ewangelia według św. Jana, s. 233.

50 Por. R. Schnackenburg, Das Johannesevangelium, s. 218-220. 
Okazuje się, że nie tylko część tłumu nie była w stanie pojmać Jezusa, ale również nie dokonały tego wysłane w tym celu straże $(7,45 ; 7,32)^{51}$. Po powrocie arcykapłani i faryzeusze zażądali od nich wyjaśnień, dlaczego nie dopełnili nałożonego na nich obowiązku. W odpowiedzi usłyszeli to, czego na pewno ci nie oczekiwali. Otóż Jezus zrobił na nich tak ogromne pozytywne wrażenie, że wynieśli Go ponad wszystkie dotychczasowe autorytety w Izraelu. Stwierdzili, że "jeszcze nikt nie przemawiał tak jak ten człowiek" $(7,46)$. To wyznanie w obecności swoich przełożonych musiało zrobić na nich bardzo negatywne wrażenie i doprowadzić ich do stanu głębokiej irytacji i złości. W celu zniszczenia autorytetu Jezusa położyli na szalę swój własny oraz zwierzchników. Zadali im pytanie, na które oczekiwali w sposób oczywisty odpowiedzi po ich myśli: „Czy ktoś ze zwierzchników lub faryzeuszy uwierzył w Niego?” $(7,48)^{52}$. Odpowiedź miała paść: oczywiście, że nie. Żeby jednak jeszcze bardziej wzmocnić siłę zastraszenia i usłyszeć oczekiwaną negatywną odpowiedź, żeby i ci nie dali się zwieść Jezusowi $(7,47)$, oskarżyli część tłumów uznającą Jezusa za Mesjasza, za ludzi przeklętych przez Boga $(7,49)^{53}$. W takim stanie rzeczy - w ich przekonaniu - jedynymi autorytetami w pełni wiarygodnymi dla strażników, powinni pozostać nadal ci, którzy byli nimi do tej pory, czyli religijne elity żydowskie. Przemawia za tym ich znajomość Prawa i jego praktyka potwierdzana przez nich w codziennym życiu, czego byli przecież świadkami ${ }^{54}$.

Cała przygotowana strategia zniszczenia autorytetu Jezusa i zatrzymania przy sobie jak największej liczby zwolenników, zostaje nieoczekiwanie dla nich podważona przez jednego z ich własnych szeregów. Oto Nikodem, członek Sanhedrynu, powołując się również na znajomość Prawa, staje w obronie potępionej części tłumu ${ }^{55}$. Każe faryzeuszom odpowiedzieć na pytanie, czy przy-

51 Zapewne zastanawia czytelnika powtarzająca się w tej scenie wyjątkowa nieskuteczność wrogów Jezusa w czynności pojmania Go. Czy w ten sposób Ewangelista nie chce dodać otuchy ewangelizatorom reprezentowanego przez siebie Kościoła? Żeby nie obawiali się tak bardzo religijnych przywódców żydowskich, ponieważ w czasach Jezusa też byli nieskuteczni, a przecież Chrystus zmartwychwstały będzie z nimi obecny przez cały czas ich misji. To On będzie przez nich dokonywał dzieła ewangelizacji swoich rodaków.

52 Należy podkreślić, że w odpowiedzi na słowa staży nie powołali się na żaden tekst Pisma.

53 Za grupę przeklętą przez Boga uważano tzw. lud ziemi, złożony z ludności mieszanej pod względem etnicznym i religijnym. Rzeczywiście nie znali oni Prawa i nie przestrzegali go, stając się przez to przedmiotem nienawiści faryzeuszy. Odmawiano im jakiejkolwiek pobożności. To właśnie spośród nich rekrutowali się zwolennicy i uczniowie Jezusa. Por. L. Stachowiak, Ewangelia według św. Jana, s. 233.

54 Por. R. Schnackenburg, Das Johannesevangelium, s. 220-222.

55 Znany już z 3,1-21. 
padkiem Prawo, na które powołali się, by uzasadnić swoje racje i działania, nie nakazuje przed wydaniem wyroku przeprowadzenia przesłuchania oskarżonych i zbadania racji ich postaw i działań? $(7,51)^{56}$. W odpowiedzi Nikodem słyszy te same argumenty o pochodzeniu Mesjasza $(7,52)^{57}$. Nadto posądzają go o brak obiektywizmu, ponieważ sam pochodzi z Galilei ${ }^{58}$.

Informacją, że wszystkie strony sporu o Jezusa (faryzeusze, arcykapłani, straże i Nikodem) rozeszli się do swoich domów (7,53), Ewangelista stwierdza również, że każda pozostała przy swoich przekonaniach i wątpliwościach. Niewiadomą pozostaje dalsza postawa straży. Czy nadal trwają w zachwycie nad Jezusem i rokują większą nadzieję na zwrócenie się ku wierze w Jezusa, czy też dali się zastraszyć swoim zwierzchnikom i pozostali im w pełni wierni? Całość narracji o dysputach w czasie Święta Namiotów Ewangelista kończy kolejnym wyeksponowaniem bezradności i nieskuteczności wszystkich działań przeciwników Jezusa. Jakiekolwiek by były podjęte przez nich samych zamiary i działania, czy też zlecone innym do wykonania, okazują się całkowicie nieskuteczne. W opisie tego zjawiska jest on nadzwyczaj konsekwentny. Na jego tle równie konsekwentnie pokazuje Jezusa jako skutecznego suwerena swego losu i działań. Czytelnik Ewangelii dostaje w ten sposób bardzo silny sygnał, że Jezus postępuje tak dlatego, ponieważ prawdziwie pochodzi od Boga i pełni Jego wolę. To wola Boga, z którą się w pełni identyfikuje, decyduje o tym co się z Nim dzieje i w przyszłości dziać będzie, a nie intrygi Jego i, jak to dobitnie wybrzmiewa w całości narracji, również Boga przeciwników ${ }^{59}$. To ważny sygnał dla Kościoła reprezentowanego przez Ewangelistę, szczególnie w obliczu pytania o sens i skuteczność podejmowania kolejnej próby ewangelizacji swoich rodaków, wrogo nastawionych do Jezusa i Jego Kościoła w czasie redakcji Ewangelii.

56 Nikodem miał zapewne na myśli Wj 23,1; Kpł 19,15 i Pwt 1,16-17; 17,4; 19,15-20. Prawo nakazywało dokładne zbadanie każdej sprawy o charakterze religijnym. Podobnie nauczała też tradycja rabiniczna (TB Sanh 5,4c; Exod Rabba 21,3). Por. A. Paciorek, Ewangelia umiłowanego ucznia, s. 323; por. L. Stachowiak, Ewangelia według św. Jana, s. 234.

57 Źródła żydowskie nic nie mówią o wykluczeniu Galilei jako ojczyzny proroków. Przeciwnie, z BT Sukka 27b dowiadujemy się, że prorocy mogą pochodzić z wszystkich pokoleń Izraela. Por. L. Stachowiak, Ewangelia według św. Jana, s. 234.

58 Por. R. Schnackenburg, Das Johannesevangelium, s. 222n.

59 Por. S. Mędala, Chrystologia, s. 306-309. 


\section{Prawość i szukanie chwały Bożej Jezusa i Kościoła}

Egzegeza sekcji J 6,60-7,53 wykazuje, że Ewangelista Jan opowiada w niej historię Jezusa z Galilei, w którą głęboko zakorzenia współczesność osobistą oraz reprezentowanego przez siebie Kościoła. Podobnie jak to było w czasie historycznej działalności Nauczyciela z Galilei, tak również w czasach, w których przyszło mu redagować Ewangelię doświadcza odejść uczniów Jezusa ze wspólnoty Kościoła, zwątpień i małej wiary jego członków oraz wrogości religijnych elit wraz z podległym mu ludem żydowskim. Mimo to, kierując się postawą Jezusa i Jego nauką, widzi konieczność ponownego zwrócenia się do wszystkich wyznawców judaizmu (Żydów), szczególnie tych w Judei, z misją ewangelizacyjną ukrzyżowanego i zmartwychwstałego Pana. Ma świadomość, że nie będzie to łatwe zadanie, ale też dobrze zdaje sobie sprawę, że niewiarą wykluczyli siebie ze sfery Bożego zbawienia, z czym nie wolno się godzić, mając na względzie Jego wolę objawioną w dziejach Izraela, osobie Jezusa i misji Kościoła. W celu przeprowadzenia jak najskuteczniejszej ewangelizacji proponuje Kościołowi jej konstytutywne kryteria, którymi charakteryzował się historyczny Jezus w czasie swojej działalności. W interesującym nas tekście są nimi: prawość i szukanie chwały Bożej. Z perspektywy czasów Ewangelisty niektórzy mogli oczywiście uważać, że sam Jezus nie odniósł nadzwyczaj spektakularnych sukcesów misyjnych w Jerozolimie. W odpowiedzi na takie zarzuty w swoim przesłaniu wyraźnie jednak podkreśla, że w czasie dysput prowadzonych podczas Święta Namiotów Jezus uzyskał wsparcie od przedstawiciela Sanhedrynu Nikodema oraz sympatię i podziw straży świątynnej, a przede wszystkich wzbudził takie uznanie wśród części ludu żydowskiego, że ta dostrzegła w Nim Mesjasza. To wszystko czyni ważnym argumentem uzasadniającym sens podjęcia misji ewangelizacyjnej wśród $Z$ zydów. Tym samym wyraża tu swe głębokie przekonanie, że każde misyjne przedsięwzięcie Kościoła, dzięki działającemu w nim Duchowi, może zwrócić kolejną część wrogo dotychczas nastawionych wyznawców judaizmu ku Bogu i Jego zbawieniu ofiarowanego im w Jego Synu i Mesjaszu. Wystarczy tylko, aby ci, którzy Go wówczas odrzucili, tym razem zwrócili się prawym sercem do Boga i Jego woli zapisanej w Pismach. Zaufali ich interpretacji ewangelicznej dokonanej przez Jezusa, a obecnie przekazywanej przez Kościół i szukali w tym wszystkim jedynie chwały ich Najwyższego Pana, a On sam da im dar właściwego poznanie Jego woli i wiary w Jezusa. Jako argument przemawiający za zgodną z Jego wolą interpretację Pism dokonaną przez Jezusa, Ewangelista wydaje się uznawać skuteczność misyjną Kościoła w świecie pogańskim. Stanowczo ostrzega Żydów, że obecna misja Kościoła okaże się bezowocna, podobnie jak poprzednia Jezusa, jeśli nadal będą kiero- 
wać się nieprawością i egoistycznym szukaniem własnej chwały. Ostrzeżenie to dotyczy również i Kościoła. Jeżeli jego ewangelizatorzy zatracą osobistą prawość i będą szukać własnej chwały, to ich działania okażą się tak samo nieskuteczne jak ówczesnych wrogów Jezusa i podobnie jak oni nie dostąpią łaski przebywania w obecności Jezusa i Jego Ojca w niebiańskiej wieczności.

\section{Bibliografia}

Gryglewicz F., Dyskusja podczas Święta Namiotów (J 7,1-52), Ruch Biblijny i Liturgiczny 35/5 (1982), s. 321-332.

Łach J., Bracia Jezusa, Studia Theologica Varsaviensia 11/2 (1973), s. 257-264.

Łach J., Znamienny zapis w dyskusji na temat pochodzenia Mesjasza (J 7,25-27.40-43), w: Duch i Oblubienica mówiq̨: „Przyjdź”, red. W. Chrostowski, Warszawa 2001, s. $24-246$.

Mędala S., Chrystologia Ewangelii św. Jana, Kraków 1993.

Okure T., Ewangelia według św. Jana, w: Międzynarodowy Komentarz do Pisma Świętego, red. W.R. Farmer, Warszawa 2000, 1302-1362.

Paciorek A., Ewangelia umiłowanego ucznia, Lublin 2000.

Schnackenburg R., Das Johannesevangelium. Herders Theologischer Kommentar zum Neuen Testament. Sonderausgabe IV/2, Freiburg-Basel-Wien 2000.

Stachowiak L., Ewangelia według św. Jana. Wstęp - przekład z oryginału - komentarz, t. IV, Poznań-Warszawa 1975.

Szymanek E., Wiara i niewiara, w: Egzegeza Ewangelii św. Jana, red. F. Gryglewicz, Lublin 1992, 259-281.

Włodarczyk S., „Skąd zna on Pisma, skoro się nie uczył?” (J 7,15), Ruch Biblijny i Liturgiczny 55/3 (2002), s. 223-231.

Wróbel M.S., Antyjudaizm a Ewangelia według św. Jana, Lublin 2005.

Żywica Z., Kościót Jezusa a judaizm i poganie według ewangelisty Mateusza. Teologia narratywna, Olsztyn 2006. 